\title{
Application of Path Analysis on Incidence of Anemia in Female Adolescents
}

\author{
Dwi Handayani ${ }^{1 *}$, Eti Poncorini Pamungkasari², Endang Sutisna Sulaeman ${ }^{2}$ \\ ${ }^{1}$ Postgraduate Program of Nutrition Sciences, Sebelas Maret University, Surakarta 57126, Indonesia \\ ${ }^{2}$ Faculty of Medicine, Sebelas Maret University, Surakarta 57126, Indonesia
}

\begin{abstract}
The aim of the study was to analyse the direct and indirect effects of knowledge, attitudes, and eating behavior on anthropometry status and anemia incidence in female adolescents. This observational study employed case-control design and involved a total with total of female adolescents 117, classified into case groups $(n=39)$ and control groups $(n=78)$. The data were collected using questionnaires on knowledge and attitude about nutrition of anemia and eating behaviors, $2 \times 24$ hour food recall, Food Frequency Questionnaire (FFQ), anthropometry, and also $\mathrm{Hb}$ level measurement by Cyanmethemoglobin method. The data were analysed using path analysis. The results showed that there was a significant relationship $(\mathrm{p}<0.05)$ and direct effects between eating behavior on anthropometry status and incidence of anemia, which accounted for $66 \%$ and $22 \%$ respectively. There was no relationship ( $>0.05)$ and indirect effects between attitude and incidence of anemia with value $4.1 \%$. Eating behavior had a strong effect on anemia incidence through anthropometry in female adolescents.
\end{abstract}

Keywords: anemia, anthropometry status, attitude, eating behavior, knowledge

\section{INTRODUCTION}

World Health Organization (WHO) defines adolescents the individuals who are in the age group of 10-19 years. This group of world's population has grown approximately 1.2 billion. In Indonesia, the number of female adolescents has reached 41 million people (UNICEF 2011). Female adolescents group is one of the vulnerable groups to having nutritional problems, especially anemia, which is one of the health nutrional problem in Indonesia, with its prevalence reaching $21.7 \%$ and more developing in females than males (MoH 2013). In Central Java, the prevalence of anemia was $57.1 \%$ (Central Java Provincial Health Office 2014).

Based on a survey by the Nutrition Promotion of Sukoharjo Districts Health Office to 1200 females in 12 schools, there were $559 \mathrm{fe}$ males $(46.58 \%$ ) had anemia (Sukoharjo Districts Health Office 2014). From these data it can be seen that the incidence of anemia in Sukoharjo is still more than $15 \%$. It is classified as public health problem according to $\mathrm{WHO}$ guidelines. (Alisjabana 2015).

The high prevalence of anemia in female adolescents can lead to various effects if not prevented. Nutritional status is one of the risk factor of anemia. Kanodia et al. (2016) in his study showed that female adolescents with a lower body mass index have risk developing anemia. Inadequate intake can be one of the factors of undernourished adolescents. In other words, eating behavior has impact of nutritional status in female adolescents. Female adolescents with a poor eating behavior such as skipping meals, drinking tea after or with meal it can induce anemia (Mazhar 2015).

Inadequate intake caused by poor eating behavior may result from the lack of nutrition knowledge, particularly about anemia. The lack of nutrition knowledge in female adolescents can affect their attitudes. According to Jalambo et al. (2017) most of female adolescents still have lack of knowledge and awareness of anemia. This study was carried out to analyse the factors that directly and indirectly effects the incidence of anemia in female adolescents.

\section{METHODS}

\section{Design, location, and time}

The study is design was a case control. Cluster random sampling technique was employed to select the location, resulting in four junior high schools in 4 sub-districts in Sukoharjo Districts. The study was carried out in the period of August-September 2017.

\footnotetext{
"Corresponding Author: tel: +6282337942669, email: dwi08.yani@gmail.com
} 


\section{Sampling}

The population in this study was female adolescents aged 13-15 years. Anemia status was used to select the subjects. The minimum sample size was calculated by using the formula of the sample size of case control study with confident levels of $95 \%(Z \alpha=1.960)$ and strength of $80 \%$ $(Z \beta=0.842), O R=3.98$, which resulted in the minimum sample being 39 . With ratio of 1:2 for case and control groups, total of subject was 117 (39 in the case and 78 in control groups). The inclusion criteria applied for control groups were female adolescents aged 13-15, Hb levels $\geq 12$ g/ $\mathrm{dl}$, having no menstruation during the study and accepting the informed consent agreement. Those who were not present and had illness/sick during this study were excluded from this study. The inclusion criteria for case groups were female adolescents aged 13-15, $\mathrm{Hb}$ levels $<12 \mathrm{~g} / \mathrm{dl}$, have no menstruation during this study. Female adolescents who had chronics illness such as Upper Respiratory Tract Infection (URTI), cancer, Tuberculosis (TB), heart disease, and another chronic disease were exclude from this study.

Ethical clearance for this study was approved by Health Research Ethics Committee Faculty of Medicine, Sebelas Maret University, Dr. Moewardi General Hospital, Surakarta. It was obtained in the form of ethical Approval No. 570/ VI/HREC/2017 and written informed consent was obtained from each.

\section{Data collection}

The data on anemia incidence are obtained by measuring the levels of hemoglobin. Blood samples were analysed with Cyanmethemoglobin method in Sarana Medika laboratory in Surakarta. The nutritional status were obtained by measuring the weight and height of the subject by using digital scales and microtoise. The data on subject characteristics such as age, maternal education, and parents income were obtained through interview. The data of knowledge, attitude, and eating behavior for female adolescents were collected with questionnaires which has been tested for validity and reliability. Based on the validity test, only 8 from 15 questions of knowledge were valid, whereas 10 items of attitudes were considered valid as many. For behavioral items, from 20 questions only 17 were valid. The reliability test showed Cronbach alpha values of $\geq 0.60$ for each item.

\section{Data analysis}

Incidence of anemia was classified according to $\mathrm{Hb}$ level, $\mathrm{Hb}<12 \mathrm{~g} / \mathrm{dl}$ in case group and
$\mathrm{Hb} \geq 12 \mathrm{~g} / \mathrm{dl}$ in control group. Nutritional status, can be measured with z-score BMI for age (Body Mass Index by age). Classifications include underweight if the $\mathrm{z}$-score $<-3.0$, wasting $\geq 3.0$ to $-2 \mathrm{SD}$, normal $\geq 2.0$ to $\leq 1.0$, overweight $>1.0$ to $\leq 2.0$, and obesity $>2.0$. The knowledge was divided into 3 categories; good $(>80 \%)$, moderate $(60-80 \%)$, and less $(<60 \%)$. A Likert scale was used to measure the attitude, which included strongly agree (5), agree (4), neutral (3), disagree (2), strongly disagree (1), subsequently the values were divided into two categories ("positive" if the mean value was $\geq 31$ and "negative" if the mean value was $<31$ ). Furthermore, a Likert scale was used to measure eating behavior included every day (5), often (4), sometimes (3), rarely (2), and never (1), the values were divided into two categories ("well" eating behavior if the mean value was $<50$ and "good" if the mean value was $\geq 50$ ).

The data were analysed by using univariate and multivariate analysis. Univariate analysis was used to analyse the distribution of subject characteristics (age, maternal education, parents income, knowledge, attitude, anthropometry status, and eating behavior). Multivariate analysis was used for the path analysis. The objective of path analysis was to analyse the direct and indirect effects of the independent variables (knowledge, attitude, behavior and eating behavior) on the dependent variables (anthropometry status, anemia incidence), which can be seen through the coefficient values that have been described in the form of diagrams with arrows in one direction to the theory.

\section{RESULTS AND DISCUSSION}

\section{Anemia status and subject's characteristic}

Anemia is a condition characterized by decreased hemoglobin levels in the blood due to reduced oxygen capacity in the body (Rati 2014). This study showed the subject accounted for $39(33.6 \%)$ subjects in the case group (anemic) and $78(66.7 \%)$ subjects in control group (nonanemic), showed in Table 1. The average of $\mathrm{Hb}$ levels in subjects was $12.57 \pm 1.44$, whereas in the case and the control group were $10.96 \pm 0.85$ and $13.39 \pm 0.87$, respectively.

Most of the female adolescents were 13 years old (84.6\%), showed in Table 1. In average of the education level of the subject's mothers were senior high school (40.1\%). Compare to the UMR (regional minimum salary) in Sukoharjo District which is Rp 1,513,000, most respondent's parents had income above the UMR (57.2\%). 
Table 1. Haemoglobin concentration on female adolescents

\begin{tabular}{lccccc}
\hline Haemoglobin consentration & Frequency & $\%$ & Mean \pm SD & Min & Max \\
\hline Anemic & 39 & 33.3 & $10.96 \pm 0.85$ & 9.0 & 11.90 \\
Non-anemic & 78 & 66.7 & $13.39 \pm 0.87$ & 12.0 & 15.50 \\
Total & 117 & 100.0 & $12.57 \pm 1.44$ & 9.0 & 15.50 \\
\hline
\end{tabular}

Table 2. Distribution of subject's characteristics

\begin{tabular}{|c|c|c|c|c|c|c|}
\hline \multirow{3}{*}{ Subject's characteristics } & \multicolumn{4}{|c|}{ Anemia status } & \multirow{2}{*}{\multicolumn{2}{|c|}{ Total }} \\
\hline & \multicolumn{2}{|c|}{ Anemic } & \multicolumn{2}{|c|}{ Non-anemic } & & \\
\hline & $\mathrm{n}$ & $\%$ & $\mathrm{n}$ & $\%$ & $\mathrm{n}$ & $\%$ \\
\hline \multicolumn{7}{|l|}{ Age (years) } \\
\hline 13 & 30 & 76.9 & 69 & 88.5 & 99 & 84.6 \\
\hline 14 & 8 & 20.5 & 7 & 9 & 15 & 29.5 \\
\hline 15 & 1 & 2.6 & 2 & 2.6 & 3 & 5.2 \\
\hline \multicolumn{7}{|l|}{ Maternal education } \\
\hline Elementary school & 8 & 20.5 & 18 & 23.1 & 26 & 22.2 \\
\hline Junior high school & 11 & 28.2 & 22 & 28.2 & 33 & 28.2 \\
\hline Senior high school & 17 & 43.6 & 30 & 38.5 & 47 & 40.1 \\
\hline Diploma/bachelor degree & 3 & 3.8 & 8 & 10.3 & 11 & 9.4 \\
\hline \multicolumn{7}{|l|}{ Income } \\
\hline High & 23 & 59 & 44 & 56.4 & 67 & 57.2 \\
\hline Low & 16 & 41 & 34 & 43.6 & 50 & 42.7 \\
\hline \multicolumn{7}{|l|}{ Knowledge } \\
\hline Good & 3 & 3.8 & 6 & 7.7 & 9 & 7.7 \\
\hline Moderate & 11 & 28.2 & 31 & 39.7 & 42 & 35.8 \\
\hline Less & 25 & 64.1 & 41 & 52.6 & 66 & 56.4 \\
\hline \multicolumn{7}{|l|}{ Attitude } \\
\hline Positive & 12 & 30.8 & 31 & 39.7 & 43 & 36.7 \\
\hline Negative & 27 & 69.2 & 47 & 60.3 & 74 & 63.2 \\
\hline \multicolumn{7}{|l|}{ Eating behavior } \\
\hline Good & 10 & 25.6 & 42 & 53.8 & 52 & 44.5 \\
\hline Very good & 29 & 74.4 & 36 & 46.2 & 65 & 55.5 \\
\hline \multicolumn{7}{|l|}{ Nutritional status } \\
\hline Underweight (-3 SD) & - & - & 1 & 1.3 & 1 & 1.3 \\
\hline Wasting ( $-3 \mathrm{SD}$ to $<-2 \mathrm{SD})$ & 3 & 7.7 & - & - & 3 & 7.7 \\
\hline Normal (-2 SD to $1 \mathrm{SD})$ & 35 & 89.7 & 66 & 84.6 & 101 & 86.3 \\
\hline Overweight ( $>1 \mathrm{SD}$ to $1 \mathrm{SD}$ ) & 1 & 2.6 & 5 & 6.4 & 6 & 7.7 \\
\hline Obese $(>2 \mathrm{SD})$ & - & - & 6 & 7.7 & 6 & 7.7 \\
\hline
\end{tabular}

\section{Knowledge}

Knowledge is one of the most important fundamental elements that form attitude and behavior. In terms of knowledge on nutrition, especially related to anemia, mostly were still in the category of lack of knowledge (56.4\%). It was indicated by most subjects who failed to answer correctly questions on the definition of anemia $(65.8 \%)$, the cause of anemia $(73.5 \%)$, the effect of anemia $(53 \%)$, the prevention of anemia 
$(58.2 \%)$, the factors that affect iron absorption related to anemia incidence (72.7\%). A study conducted by Hafiz (2015) showed that only 25\% of female adolescents had a good knowledge about anemia. Notoatmodjo (2010) expounded that behaviors that are based on knowledge will last longer than behaviors that are not based on knowledge.

\section{Attitude}

Attitude is a reflection of evaluation or reaction of feelings (Azwar 2009). Table 2 showed that most of female adolescents attitude were negative $(63.2 \%)$, both in the case or control groups with mean score less than 31 . It is proven by the fact that there are female adolescents who did not agree with the ideas that increasing the consumption of iron-containing supplements can prevent anemia (45.2\%), they assumed that anemia is not a health problem $(4.2 \%)$, and they ignored the fact that anemia can interfere with school activities (18.8\%). Ranjitha (2016) stated that female adolescents are in high risk to develop anemia eventhough they have good knowledge but do not implement the knowledge and have negative attitude.

\section{Eating behavior}

Eating behavior is the behaviors reflecting a one's manners, meal frequency, food pattern, eating habit, and the food choice. In this study most of the female adolescents were classified in the category of well eating behavior $(55.5 \%)$ with a mean score of $<50.74 .4 \%$ of female adolescents who had very good eating behavior had anemia. This is indicated in the data that some female adolescents skipped meals (34\%), rarely consumed animals protein $(35 \%)$, rarely eat vitamin $\mathrm{C}$-containing fruits $(32.4 \%)$, eating unhealthy snack $(35.8 \%)$, liked to eat fast food (35.8\%), drank tea/coffee during meal $(92.3 \%)$, limited dietary intake $(50.7 \%)$, and had no information about anemia (26.4\%). Unhealthy eating behaviors, such as high frequency of eating junk food $(81.5 \%)$ and skipping meals $(96.6 \%)$ are significantly associated with anemia (Jethva 2014).

\section{Anthropometry status}

Anthropometry status is a state of the body as a result of consumption, absorption, and the use of nutrients or physiological conditions due to the availability of nutrients in the body. Anthropometry status of female adolescents in Sukoharjo Districts was mostly normal (86.3\%). A total of $3(7.7 \%)$ of wasting female adolescents were anemia and $1(2.6 \%)$ overweight female adolescents developed anemia. Female adolescents who are underweight or wasting are more susceptible to anemia, it is because the food intake is less than their needs so that the amount of nutrients that are absorbed is also low. Macronutrients (carbohydrates, fats, and proteins) are closely related to anthropometry status as well as micronutrients (vitamins and minerals). Inadequate intake it can be effect on anthropometry status and anemia status. Both inadequate nor excessive intake may affect the nutritional and anemia statuses (Kartini 2014).

\section{Path analysis}

Table 3 model 1 shows there was no significant relationship between knowledge and anthropometry status ( $\mathrm{p}=0.123$ ). It is line to Kinyua (2013) that there is no significant relationship between knowledge and anthropometry status in female adolescents in Nairobi. It contrast with Pahlevi (2012) who states there was a significant relationship between knowledge and anthropometry status. The reason behind no significant relationship between nutritional knowledge and anthropometry status can be seen from some subject's age of this study which are mostly 13 years old $(84.6 \%)$. For the most part, at the age, determining the type of food and meal preparation process still depends on parents, especially mothers.

Model 2 shows that there was no significant relationship between nutritional knowledge of anemia and the anemia occurence with $(p=0.227)$. Similarly, Suryani (2015) stated there was no relationship between knowledge and anemia incidence. There was no relationship between attitudes and nutritional status in female adolescents $(\mathrm{p}=0.065)$, as it can seen from Table 3 model 1 . Similar study with Kinyua (2013) that there was no significant relationship between attitude and anthropometry status.

Table 3 model 1, it can be concluded that there was a significant relationship between eating behavior and anthropometry status $(\mathrm{p}=0.000)$. It is similar to Syed et al. (2016) who found that there is a significant relationship between eating behavior and anthropometry status. The variables of eating behavior with anemia occurrence showed a significant relation $(\mathrm{p}=0.045)$ which can be seen in Table 3 model 2. Megawati (2016), in her study also maintained that anemia in female adoescents it can be affected by eating behavior. 
Table 3. Model of coefficient path analysis on incidence of anemia in female adolescents

\begin{tabular}{|c|c|c|}
\hline Model & Coefficient & Significance \\
\hline \multicolumn{3}{|l|}{ Model 1} \\
\hline Knowledge & -0.106 & 0.123 \\
\hline Attitude & -0.128 & 0.065 \\
\hline Eating behavior & 0.666 & 0.000 \\
\hline \multicolumn{3}{|l|}{ Model 2} \\
\hline Knowledge & 0.100 & 0.227 \\
\hline Eating behavior & 0.222 & 0.045 \\
\hline Anthropometry status & 0.321 & 0.004 \\
\hline
\end{tabular}

Direct influence of knowledge, attitude, and eating behavior with anthropometry status and anemia status.

According from path analysis (Figure 1), it can be seen that eating behavior had a strong effects on the other variables. The result shows that there was a positive and direct relationship between eating behavior and anthropometry status with a coefficient value of 0.666 . It means that $66 \%$ of the anthropometry status of female adolescents is directly affected by eating behavior, the remaining $34 \%$ are affected by other factors. In the other hand, there is a direct effect and positive relationship between eating behavior of female adolescents and anemia occurrence (coefficient value of 0.222). It means that the better behavior of female adolescents, the lower anemia occurrence is $22 \%$ of eating behavior directly affects the incidence of anemia in female adolescents, the remaining $78 \%$ are affected by other factors.
Based on Figure 1, the coefficient of the path indicates that there was a negative relationship between knowledge and anthropometry status (coeficient value -0.106). It means that nutritional knowledge can affect nutritional status in $10.6 \%$, the remaining $89.4 \%$ are influenced by other factors. Knowledge is one of the important fundamental aspects that form attitudes and behavior. In contrast, there is a direct and positive relationship between knowledge and anemia occurence (coefficient value of 0.100). It means that the better nutritional knowledge, the lower the occurenceof anemia in female adolescents in Sukoharjo Districts. Nutitrional knowledge of anemia in female adolescents affect $10 \%$ of anemia occurrence, the remaining $90 \%$ are affected by other factors.

From the results of path analysis presented in Figure 1, it can be seen that there is direct, negative effects of attitude on nutritional status in female adolescents (path coefficient of

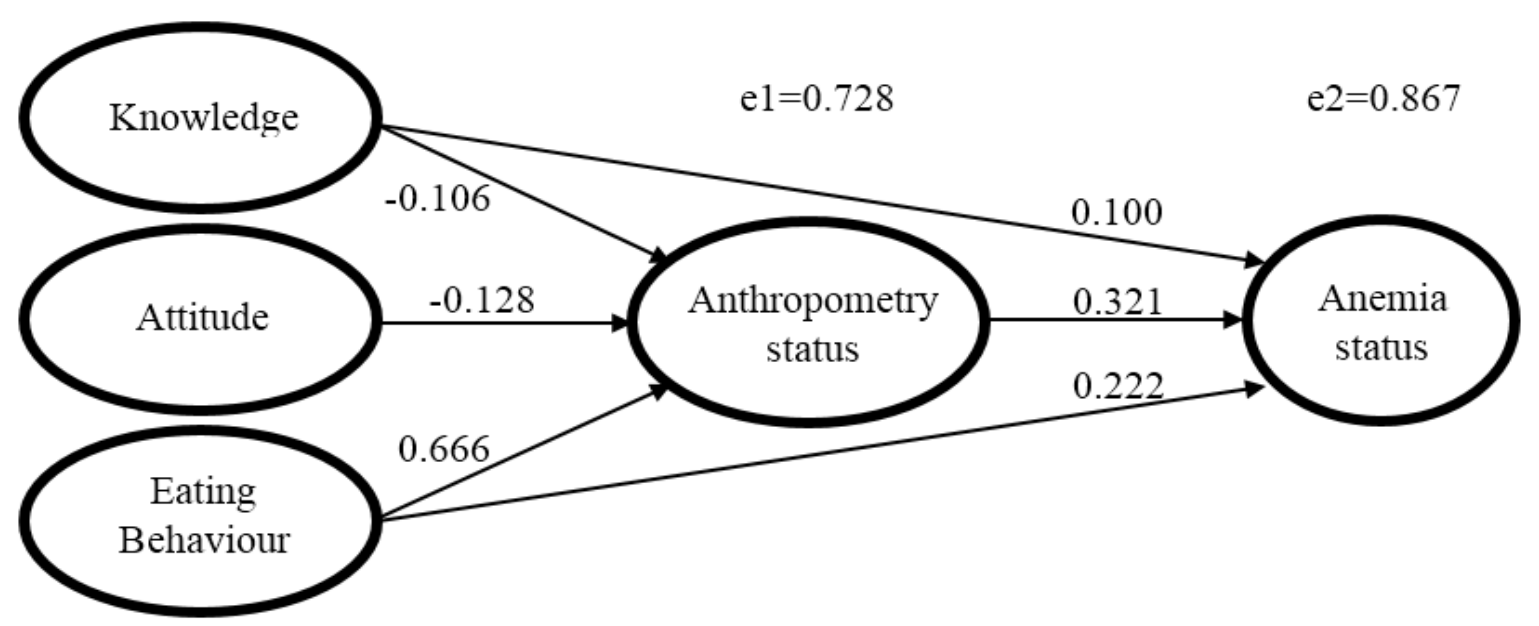

Figure 1. Path analysis diagram 
-0,128). It means that attitude can affect nutritional status for $12.8 \%$, the remaining $81.2 \%$ are affeted by other factors.

Indirect effects of knowledge, attitude, and eating behavior with anthropometry status and anemia status

In this study, it can be concluded that attitude variable has an indirect effect on the occurrence of anemia. It is an indirect influence because nutrition-related attitude must affect anthropometry status first before proceeding to anemia occurrence. Based on Figure 1 above, anthropometry is a mediator variable it can also be seen that there was no significant relationship between nutritional attitude of anemia and anemia occurrence in female adolescents $(\mathrm{p}=0.234)$. The statement is parallel with Royani et al. (2016), showing that there is no significant relationship between nutrition attitudes and the incidence of anemia. in contrast, Jose (2016) stated that there is a significant relationship between nutrition attitude and anemia occurrence in women of childbearing age. The path analysis diagram shows that nutritional attitude did not directly influence anemia occurrence, however it must pass the variable mediator, that is anthropometry status.

As shown in Figure 1, there was an indirect effect and negative relationship between attitude and anemia occurrence which (-0.041). 4.1\% of nutritional attitudes affects anemia occurrence in female adolescents, the remaining $95.9 \%$ of it influenced by other factors. Figure 1 and Table 3, show that the anthropometry status functions as the mediator variable that directly affect anemia occurrence. It is indicated by the value of the path 0.321 and is significant $(p=0.004)$. It means that the anthropometry status has an influence on anemia occurrence in female adolescents of $32.1 \%$, the remaining $67.9 \%$ are affected by other factors. Tesyafe et al.(2015) stated that there is a significant relationship between anthropometry status and anemia occurrence. Similarly, the study conducted by Ramzi et al. (2011) found that there is a significant relationship between both variables and that anthropometry status is one of the factors that cause anemia in female adolescents. This study found that some of female adolescents who had poor anthropometry status and were overweight suffered anemia.

The person who has poor anthropometry status due to nutritional intake will gradually experience wasting. Metabolism in the body becomes slower, energy and oxygen needs will be reduced so that the red blood cells (which are needed to carry the oxygen throughout the body) will also be reduced. On the other hand, when nutritional intake decreases, some micronutrients required in the formation of red blood cells are restricted (Zimmerman 2007).

Female adolescents who are overweight and obese may also suffer anemia. The occurrence of anemia in this group can be caused by several factors, such as genetic/race factors and inadequate intakes of iron rich-foods (Nead 2004). In addition, chronic inflammation and increased leptin production in obese will also increase the secretion of hepcidin from the liver. The hepcidin may reduce iron absorption (Nadia et al. 2010).

\section{CONCLUSION}

There is no relationship between knowledge and nutritional attitude, and anthropometry status and anemia occurrence in female adolescents. There is a significant relationship between eating behavior and anthropometry status and anemia occurrence. Based on the path analysis diagram, there is a direct effect of the variables of knowledge, attitude, eating behavior on anthropometry status, and knowledge, eating behavior on anemia occurrence. Attitude does not directly affect anemia occurrence. The most influential variable on anthropometry status and anemia occurrence was eating behavior. Good cooperation between school and local health officials is required to regularly educate female adolescents about anemia in order to change the behavior. Next research needs to conducted more focus on another variables related to anemia occurrence in female adolescents.

\section{ACKNOWLEDGEMENT}

Researcher would like to thank to Public Health Service of Sukoharjo Districts and schools that had given permission to conduct research in Sukoharjo Districts and helped us accomplishing this study. In this study, the authors have no conflict of interest.

\section{REFERENCES}

Alisjabana B, Karyadi E, Widjaja M, Octavia L. 2015. Status mikronutrien remaja putri dengan riwayat berat badan lahir rendah. J Gizi Pangan 10(2):117-124. 
Azwar S. 2009. Sikap Manusia Teori dan Pengukurannya. Yogyakarta : Pustaka Pelajar.

Central Java Provincial Health Office. 2014. Profil Kesehatan Provinsi Jawa Tengah Tahun 2014. Semarang: Central Java Provincial Health Office.

Hafiz A, Pareek P. 2015. A study on anemia related knowledge among adolescent girls. Int J of Nutr Food Sci 4(3):273-276. http:// doi:10.11648/j.ijnfs.20150403.14.

Jalambo MO, Naser IA, Sharif R, Karim NA. 2017. Knowledge, attitude and practice of iron deficient and iron deficient anemic adolescents in the gaza strip, Palestine. Asian $\mathrm{J}$ clin Nutr 9(1):51-56.

Jethva V, Joshi AH, Patel N. 2014. Changing food patern in adolescents and impact on health. Int J of Medical Science and Public Health 3(12):1442-1445. http://doi: 10.5455/ijmsph.2014.030920141.

Jose S, Antony CS, Isaac BR. 2016. Impact of knowledge, attitude, and practice on anemia status among women in coastal kochi, kerala. Int.J of Multidisciplinary and Current Research 4:295-298.

Kanodia P, Bhatta M, Singh RR, Bhatta KN, Shankar Shah G. 2016. A study of anemia among adolescent girls in eastern part of nepal. J of College of Med Sciences-Nepal 12(1):19-22.

Kartini A, Indartanti D. 2014. Hubungan status gizi dengan kejadian anemia pada remaja putri. J of Nutrition College 3(2):33-39.

Kinyua L.W. 2013. Association of nutrit.Ion knowledge and attitude with dietary practices and nutritional status of female undergraduate students attending university colleges within nairobi metropolis [Dissertasion]. Nairobi: Department of Food Science, Nutrition, Technology.

Mazhar S. 2015. Prevalence of anemia and dietary iron intake among female adolescents (grade 8-12) in lahore. J of Dow University of Health Science Karachi 9(3):99-105.

Megawati M. Hubungan status gizi dan pengetahuan remaja putri MA athoriyah kecamatan cikatomas kabupaten tasikmalaya. 2016. J Kesehatan Bakti dan Husada 16 (1):126-135.

[MOH] Ministry of Health. 2013. National Basic Health Report (Riskesdas) 2013. Jakarta: Ministry of Health Republic of Indonesia.

Nadia FF, Naomi JS, Yara K, Romain AMD, Alidon MB, Inge DB. 2010. Weight status and iron deficiency among urban malian women of reproductive age. British J Vol 105 (4):574-579.

Nead KG, Halterman JS, Kaczorowski JM, Auinger P, Weitzman M. 2004. Overweight and adolescents: A risk group for iron deficiency. Pediatrics 114(1):104-108.

Notoatmodjo S. 2010. Pendidikan dan Perilaku Kesehatan. Jakarta: Rineka Cipta.

Pahlevi AE. 2012. Determinan status gizi pada siswa sekolah dasar. J Kesehatan Masyarakat (7):122-126.

Ranjitha A, Angadi N. 2016. Knowledge, attitude, and practice about anemia among adolescent girls in urban slums of davengere city, karnataka. Int $\mathrm{J}$ of Medical Science and Public Health 5 (3) : 416-419.

Ramzi M, Haghpanah S, Malekmakan L, Cohan N, Baseri A, Alamdari A, Zare N. 2011. Anemia and iron deficiency in adolescent school girls in kavar urban area, southern iran. Iran Red Crescent Med J 13(2):128133.

Royani I, Patimah S, Mursaha A, Thaha A.R. 2016. Knowledge, attitude and practice of balanced diet and correlation with hypochromic microcytic anemia among adolescents school girls in maros district, south sulawesi, Indonesia. Biomed Research 27(1):165-171

Suryani D, Hafiani R, Junita R. 2015. Analisis pola makan dan anemia gizi besi pada remaja putri Bengkulu. J Kesehatan Masyarakat Andalas 10(1):11-18.

Sukoharjo Districts Health Office. 2014. Profil Kesehatan Kabupaten Sukoharjo Tahun 2014.

Syed A, Din Z, Zeb F, Ghaffar F, Khan S, Iqbal, M, Ali Khan B. 2017. Eating attitude related to the nutritional status of university girls in Peshwawar Khyber Pakhtunkhwa, Pakistan. J Clin Nutr and Dietetics 3(1):18.

Tesyafe M,Yemane T, Adisu W, Asres Y, Gedefaw L. 2015. Anemia and iron deficiency among school adolescents : burden, severity, and determinant factors in southwest ethiopia. Adolescent Health, Medicine, and Therapeautic 6:189-196.

[UNICEF] United Nations Children's Fund. 2011. The State of The World's Children : Adolescence An Age of Opportunity. United Nations Children's Fund (UNICEF). https://www.unicef.org/ado- 
Handayani et al.

lescence/files/SOWC_2011_Main_Report_EN_02092011.pdf. (Last accessed on January, 20 2017).
Zimmerman MB, Klaus K. 2007. Nutritional Anemia. Swittzerland: Sight and Life Press p:218. 